\section{KAJIAN HUKUM TERHADAP PEMBLOKIRAN PADA BUKU TANAH DALAM PENDAFTARAN TANAH $^{1}$}

Oleh: Hendra Kusuma Putra Setiyabudi ${ }^{2}$

J. Ronald Mawuntu ${ }^{3}$

Cornelius Tangkere $^{4}$

\section{ABSTRAK}

Penelitian ini bertujuan untuk mengetahui pengaturan pemblokiran dan mekanisme pemblokiran pada buku tanah dalam pendaftaran tanah yang dapat menjamin kepastian hukum bagi pihak pemegang hak atas tanah. Penelitian hukum yang bersifat akademis berkaitan dengan upaya untuk memberikan sumbangan pemikiran bagi perkembangan ilmu hukum melalui temuan teori hukum, argumentasi baru, atau konsep baru terhadap hal-hal yang dipandang telah mapan dalam ilmu hukum. Selanjutnya dari hasil yang dicapai tersebut akan memberikan preskripsi mengenai apa yang seyogyanya atas isu hukum yang diajukan. Hasil penelitian menunjukkan bahwa Pengaturan Pemblokiran Pada Buku Tanah Dalam Sistem Pendaftaran Tanah dapat dilihat dari 3 (tiga) aspek yaitu pertama aspek filosofis dan aspek yuridis serta aspek pengaturan pemblokiran antisipasi atau pencegahan secara dini terhadap perbuatan hukum atas sebidang tanah yang sedang dalam perkara ataupun sita sehingga tidak akan menimbulkan kerumitan di kemudian hari dalam menindaklanjuti penyelesaian atas masalah yang ada. Mekanisme pemblokiran pada buku tanah dalam pendaftaran tanah belum dapat menjamin kepastian hukum bagi pihak pemegang hak atas tanah di karena belum dilaksanakan berdasarkan peraturan perundang-undangan bidang pertanahan yang mengatur tentang pemblokiran serta terdapat hambatan yang menyebabkan kepastian hukum belum dapat tercapai antara lain penggunaan teknologi yang belum diselaraskan dengan peraturan perundang-undangan serta ketakutan aparat BPN untuk konsisten dalam melakukan penghapusan setelah jangka waktu 30 hari akibat $p$

\footnotetext{
${ }^{1}$ Artikel Tesis.

${ }^{2}$ Mahasiswa pada Pascasajana Unsrat Manado. NIM. 18202108056

${ }^{3}$ Fakultas Hukum Unsrat, Guru Besar IImu Hukum

${ }^{4}$ Fakultas Hukum Unsrat, Doktor IImu Hukum
}

emahaman aparat penegak hukum yang belum sepenuhnya mengetahui mekanisme pemblokiran.Kata kunci: Kajian Hukum, Pemblokiran, Buku Tanah, Pendaftaran Tanah

\section{A. Latar Belakang}

Bumi, air dan kekayaan alam yang terkandung di dalamnya dikuasai oleh negara dan dipergunakan untuk kemakmuran rakyat merupakan ketentuan dalam Pasal 33 ayat (3) Undang-undang Dasar Negara Republik Indonesia Tahun 1945 (UUD NRI 1945). Untuk melaksanakan ketentuan tersebut diterbitkan Undang-undang No. 5 Tahun 1960 tentang Peraturan Dasar Pokok-pokok Agraria di mana dalam Pasal 19 ditegaskan bahwa untuk kepentingan kepastian hukum dalam pertanahan maka diselenggarakan suatu pendaftaran tanah di Indonesia.

Pendaftaran tanah di Indonesia kemudian diatur dalam Peraturan Pemerintah No. 10 Tahun 1961 tentang Pendaftaran Tanah yang kemudian diganti dengan Peraturan Pemerintah No. 24 Tahun 1997 tentang Pendaftaran Tanah di mana dalam Pasal 3 ditegaskan bahwa tujuan pendaftaran tanah adalah untuk memberikan kepastian hukum dan perlindungan hukum kepada pemegang hak atas suatu bidang tanah, satuan rumah susun dan hak-hak lain yang terdaftar agar dengan mudah dapat membuktikan dirinya sebagai pemegang hak yang bersangkutan, untuk menyediakan informasi kepada pihakpihak yang berkepentingan termaksud pemerintah agar dengan mudah, dapat memperoleh data yang diperlukan dalam mengadakan perbuatan hukum mengenai bidang-bidang tanah dan satuan-satuan rumah susun yang sudah terdaftar, untuk terselenggaranya tertib administrasi pertanahan.

Terselenggaranya pendaftaran tanah secara baik merupakan dasar dan perwujudan, tertib administrasi di bidang pertanahan; untuk mencapai tertib administrasi tersebut disetiap bidang tanah dan satuan rumah susun termasuk peralihan, pembebanan dan hapusnya wajib didaftarkan. Pendaftaran tanah menciptakan hubungan seseorang dengan tanah yang dimilikinya dan untuk memberikan kepastian hukum maka diberikan tanda pemilikan tanah yang disebut sertipikat 
hak dan untuk hak milik disebut sertipikat hak milik atas tanah. ${ }^{5}$

Salah satu indikasi kepastian objek hak atas tanah ditunjukkan oleh kepastian letak bidang tanah yang berkoordinat georeferensi dalam suatu peta pendaftaran tanah, sedangkan kepastian subjek diindikasikan dari nama pemegang hak atas tanah tercantum dalam buku pendaftaran tanah pada instansi pertanahan. Hal ini dianggap perlu karena kebutuhan akan tanah dan permintaannya pun akan semakin meningkat sementara persediaan yang terbatas dengan harga yang semakin meningkat sering menimbulkan benturan kepentingan, yang kemudian menimbulkan sengketa, konflik dan/atau perkara pertanahan. Timbulnya sengketa, konflik dan/atau perkara pertanahan pada dasarnya merupakan salah satu permasalahan dalam bidang pertanahan yang perlu diatasi karena dapat menimbulkan konflik berkepanjangan bahkan perpecahan. ${ }^{6}$

Keberadaan sertipikat hak atas tanah sebagai surat tanda bukti hak memiliki kekuatan sempurna. Hal ini berarti bahwa selama tidak dapat dibuktikan sebaliknya data fisik dan data yuridis yang tercantum di dalamnya harus diterima sebagai data yang benar. Parlindungan mengemukakan bahwa pasal 19 UUPA menyatakan bahwa sertifikat adalah sebagai alat pembuktian yang kuat, sehingga setiap orang dapat mempermasalahkan tentang kebenaran sertifikat tanahnya, dan jika dapat dibuktikan ketidakbenaran dari hak atas tanah tersebut, maka sertifikat dapat dibatalkan oleh Pengadilan dan Kepala BPN dapat memerintahkan hal tersebut. Pembatalan sebuah sertipikat tentu saja tidak dapat dilakukan dengan sewenang-wenang tetapi melalui mekanisme dan prosedur yang tetap menjamin kepastian hukum bagi pemegang hak atas tanah. $^{7}$

\footnotetext{
Urip Santoso. 2010. Hukum Agraria, Kajian Komprehensif. Kencana : Jakarta. (75)

${ }^{6}$ Iwan Permadi. Perlindungan Hukum Terhadap Pembeli Tanah Bersertifikat Ganda Dengan Cara Itikad Baik Demi Kepastian Hukum, Jurnal Yustisia, Volume 5 No. 2 MeiAgustus 2016. (451)

${ }^{7}$ Sri Wijayanti. 2010. Kepastian Hukum Sertipikat Hak Atas Tanah Sebagai Bukti Hak Kepemilikan Tanah (Studi Kasus Putusan MA Tentang Sengketa Tanah Meruya Selatan), Tesis, Universitas Diponegoro : Semarang. (54).
}

Peningkatan kebutuhan akan tanah menjadi realitas yang tidak dapat dibantah dan hal ini menjadi salah satu penyebab semakin banyaknya sengketa dan perkara pertanahan yang terjadi. Dalam hal terjadinya sengketa dan perkara pertanahan, dalam sistem pendaftaran tanah di Indonesia yang diatur dalam Pasal 126 Peraturan Kepala Badan Pertanahan Nasional No. 3 Tahun 1997 tentang Pelaksanaan Peraturan Pemerintah No. 24 Tahun 1997 tentang Pendaftaran tanah dikenal suatu istilah yaitu pencatatan dalam buku tanah dan istilah status quo. Selanjutnya dalam Peraturan Menteri Agraria No. 13 Tahun 2017 tentang Tata Cara Blokir dan Sita, dikenal istilah pemblokiran.

Penggunan istilah pemblokiran dalam Peraturan Menteri Agraria No. 13 Tahun 2017 pada dasarnya bukanlah merupakan istilah yang sama dengan kata pencatatan buku tanah yang diatur dalam Peraturan Menteri Negara Agraria/Kepala Badan Pertanahan Nasional No. 3 tahun 1997 karena terdapat perbedaan yang jelas antara pemblokiran dan pencatatan dalam buku tanah. Peraturan Pemerintah No. 24 Tahun 1997 dan Peraturan Menteri Negara Agraria/Kepala Badan Pertanahan Nasional No. 3 tahun 1997(selanjutnya disingkat PMNA/Ka BPN No. 3 Tahun 1997) tidak mengenai istilah pemblokiran tetapi hanya pencatatan dalam buku tanah. Sementara itu dalam Peraturan Menteri Agraria No. 13 Tahun 2017 dikenal istilah pencatatan blokir yaitu tindakan administrasi Kepala Kantor Pertanahan atau pejabat yang ditunjuk untuk menetapkan keadaan status quo (pembekuan) pada hak atas tanah yang bersifat sementara terhadap perbuatan hukum dan peristiwa hukum atas tanah tersebut.Buku tanah dalam PMNA/Ka BPN No. 3 Tahun 1997 adalah dokumen dalam bentuk daftar yang memuat data yuridis dan data fisik suatu obyek pendaf-taran tanah yang sudah ada haknya.

Peraturan pertanahan terkait pencatatan buku tanah ataupun pencatatan blokir pada dasarnya memberikan hak kepada seseorang yang merasa terlanggar haknya atas sebidang tanah untuk mencegah terjadinya suatu perbuatan hukum pada saat sengketa atau perkara sedang berlangsung namun hak ini diberikan batasan jangka waktu yaitu 30 (tiga puluh) hari kecuali terdapat penyelesaian baik 
musyawaran maupun melalui pengadilan sebagaimana diatur dalam Pasal 126 Peraturan Mneteri Negara Agraria/Kepala Badan Pertanahan Nasional No. 3 Tahun 1997 tentang Peraturan Pelaksanaan Peraturan Pemerintah No. 24 Tahun 1997 tentang Pendaftaran Tanah. Ketentuan pemblokiran kemudian mengandung beberapa permasalahan antara lain sebagai berikut :

1. Pengajuan pencatatan pemblokiran oleh pihak yang merasa haknya terlanggar diajukan tanpa melalui mekanisme yang diatur dalam ketentuan mengenai tata cara pemblokiran ;

2. Penghapusan pencatatan pemblokiran tidak dilaksanakan berdasarkan ketentuan mengenai tata cara blokir;

3. Pengaturan jangka waktu pemblokiran dalam Peraturan Menteri Agraria No. 13 Tahun 2017 tidak sejalan dengan jangka waktu pelaksanaan perkara di pengadilan;

Dalam pra penelitian di kantor pertanahan Kota Manado diperoleh data bahwa pelaksanaan pencatatan dalam buku tanah dilaksanakan berdasarkan surat permintaan dari salah satu pihak dan dengan adanya surat permintaan tersebut, maka pencatatan dalam buku tanah dilaksanakan tanpa melalui pengkajian mengenai beralasan tidaknya pengaduan tersebut. Hal ini jelas bertentangan dengan ketentuan dalam Peraturan Menteri Agraria No 13 Tahun 2017 di mana sebuah permohonan pemblokiran haruslah didaftarkan melalui loket pendaftaran dan diterima atau ditolaknya permintaan tersebut melalui proses pengkajian oleh seksi terkait. Tindakan pemblokiran sertipikat hak tanah antara terjadi di Kota Manado dalam kasus antara Wenny Lumentut dengan PT Maybank. Pihak Wenny Lumentut menyatakan bahwa pemblokiran sertipikat secara sepihak oleh Kantor Pertanahan Manado merupakan tindakan yang tidak dapat dibenarkan. $^{8}$

Fenomena yang kemudian muncul dalam pemblokiran terhadap sertipikat hak atas tanah adalah timbulnya status quo terhadap sertipikat tanpa mempertimbangkan jaminan kepastian hukum pemegang hak sehingga

\footnotetext{
${ }^{8}$ https://kumparan.com/manadobacirita/perkarakanmaybank-legislator-gerindra-sulut-tunjuk-6-pengacara1sJWWCRIboA/full
}

seorang pemegang hak mengalami kesulitan melakukan peralihan meskipun pihak yang mengajukan permintaan blokir tidak mengajukan upaya penyelesaian sehingga sebuah pencatatan buku tanah pun tetap menjadi penghalang pemegang hak untuk melakukan perbuatan hukum meskipun pencatatan itu telah melewati batas 30 hari sebagaimana diatur baik dalam Peraturan Menteri Negara Agraria No. 3 Tahun 1997 maupun Peraturan Menteri Agraria No. 13 Tahun 2017. Hal ini menimbulkan suatu issu penelitian yaitu tidak terwujudnya jaminan kepastian hukum pemegang hak karena tidak terlaksananya mekanisme pemblokiran yang sesuai dengan ketentuan dalam peraturan perundang-undangan sehingga peneliti tertarik untuk melakukan penelitian dan pengkajian untuk mengetahui pengaturan pemblokiran dan mekanisme pemblokiran pada buku tanah dalam pendaftaran tanah yang dapat menjamin kepastian hukum bagi pihak pemegang hak atas tanah.

\section{B. Metode Penelitian}

Terry Hutchinson membedakan penelitian menjadi empat yaitu: pure basic research, strategic basic research, applied research dan experimental development. Hutchinson menempatkan penelitian hukum di dalam kategori applied research. la membedakan penelitian hukum menjadi 4 tipe, yaitu: 1) Doktrinal research, 2) Reform oriented research, 3) theoretical research dan 4) fundamental research. ${ }^{9}$ Sesuai dengan judul dan isu hukum yang diangkat, pengkajian hukum dalam penelitian ini akan difokuskan pada perspektif hukum perdata yang didukung oleh konsep filsafat hukum dan teori hukum serta didukung oleh konsep hukum administrasi. Penelitian hukum ini merupakan suatu proses untuk menemukan aturan hukum, prinsipprinsip hukum maupun doktrin-doktrin hukum yang dapat digunakan untuk menjawab isu hukum. Penelitian hukum ini dilakukan sebagai suatu kajian akademis ${ }^{10}$. Penelitian hukum yang bersifat akademis berkaitan dengan upaya

\footnotetext{
${ }^{9}$ Terry Hutchinson. 2002. Researching and Writing In Law. Law Book CO Pyrmon : NSW , (7)

10 Peter Mahmud Marzuki. 2002. Penelitian Hukum, Yuridika (Jurnal IImu Hukum Fakultas Hukum Universitas Airlangga Surabaya Vol. 16 No. 2. (14)
} 
untuk memberikan sumbangan pemikiran bagi perkembangan ilmu hukum melalui temuan teori hukum, argumentasi baru, atau konsep baru terhadap hal-hal yang dipandang telah mapan dalam ilmu hukum. Selanjutnya dari hasil yang dicapai tersebut akan memberikan preskripsi mengenai apa yang seyogyanya atas isu hukum yang diajukan.

\section{PEMBAHASAN}

\section{A. Pengaturan Pemblokiran Pada Buku Tanah Dalam Sistem Pendaftaran Tanah \\ 1. Landasan Filosofis}

Pendaftaran hak atas tanah merupaka kegiatan yang beraspek administrasi sehingga kegiatan tersebut dilaksanakan pada dasarnya merupakan bentuk pengadministrasian atas hak-hak atas tanah dan sebagai sebuah kegiatan administrasi maka pendaftaran tanah harus mampu mencegah timbulnya permasalahan yang lebih rumit apabila sebidang tanah yang telah terdaftar diajukan keberatan atau gugatan oleh pihak lain. Oleh karena itulah sehingga perlu dibentuk sebuah aturan mengenai peemblokiran hak atas tanah. Pengaturan pemblokiran ini memiliki tujuan untuk mencegah timbulnya peralihan hak atas tanah yang sedang menjadi objek sengketa, objek hak tanggungan, objek perkara baik pidana, tatausaha negara maupun pidana.

Pandangan di atas menunjukkan bahwa keberadaan lembaga pemblokiran dalam pendaftaran tanah adalah bentuk perlindungan hukum kepada pihak -pihak yang berkaitan dengan sebidang tanah sehingga ketika sebuah permasalahan telah selesai, bidang tanah yang menjadi objek sengketa ataupun perkara, tidak mengalami perubahan hak. Peneliti mencermati bahwa secara filosofis, pemblokiran buku tanah adalah sebuah bentuk perlindungan preventif yang diberikan oleh negara terhadap beberapa pihak yaitu:

a. Perlindungan hukum kepada pihak yang mengajukan permohonan pemblokiran agar terjaga bentuk dan status bidang tanah yang sedang menjadi objek sengketa, konflik atau pun perkara.

b. Perlindungan hukum kepada pihak ketiga yang dapat menderita kerugian apabila ia menerima peralihan hak atas sebidang tanah yang sedang menjadi objek sengketa, konflik dan perkara. c. Perlindungan hukum kepada pemilik tanah atau pemegang hak atas tanah untuk tetap dapat mempertahankan hak atas tanahnya secara leluasa tanpa adanya beban kepada pihak lain apabila ia melakukan peralihan atas tanah tersebut baik dalam bentuk jual beli, tukar menukar, hibah, ataupun hak tanggungan.

Jadi, pengaturan pemblokiran buku tanah adalah merupakan bentuk perlindungan hukum preventif atas kemungkinan timbulnya kerugian beberapa pihak dalam hal terjadinya sengketa, konflik atau perkara atas sebidang tanah yang telah terdaftar haknya.

\section{Landasan Yuridis}

Landasan yuridis adalah uraian tentang ketentuan-ketentuan hukum yang harus menjadi acuan dalam pembentukan peraturan perundang-undangan. Landasan yuridis dapat dibedakan menjadi landasan yuridis formal yaitu ketentuan-ketentuan hukum yang menunjuk atau memberi kewenangan kepada lembaga/organ atau lingkungan jabatan untuk membuat suatu peraturan perundangundangan dan landasan yuridis material yaitu ketentuan-ketentuan hukum yang menetukan isi dari pada peraturan perundang-undangan yang dibentuk. ${ }^{11}$

Muara dari suatu aspek yuridis adalah kepastian hukum. Dalam bab II tesis ini telah diuraikan bahwa Kepastian hukum dapat dilihat ketika suatu peraturan dibuat dan diundangkan secara pasti karena mengatur secara jelas dan logis. Jelas dalam arti tidak menimbulkan keragu-raguan (multi tafsir) dan logis dan jelas dalam arti ia menjadi suatu sistem norma dengan norma lain sehingga tidak berbenturan atau menimbulkan konflik norma. ${ }^{12}$ Kepastian hukum menunjuk kepada pemberlakuan hukum yang jelas, tetap, konsisten dan konsekuen yang pelaksanaannya tidak dapat dipengaruhi oleh keadaan-keadaan yang sifatnya subjektif. Kepastian dan keadilan bukanlah sekedar tuntutan moral, melainkan mencirikan hukum.

\footnotetext{
${ }^{11}$ Isdiyana Kusuma Ayu. Kepastian Hukum Penguasaan Tanah Melalui Pendaftaran Tanah Sistematis Lengkap Di Kota Batu. Jurnal Mimbar Hukum Volume 31, Nomor 3, Oktober 2019. (339).

12 Fadli Zon, Muhammad Iskandar dan Susanto Zuhdi. Tinjauan Sejarah Hukum Pasal 33 Uud 1945 Sebagai Ideologi Ekonomi. Jurnal Negara Hukum, Volume 7 No. 1 Tahun 2016. (113)
} 
Suatu hukum yang tidak pasti dan tidak mau adil bukan sekedar hukum yang buruk. ${ }^{13}$

Dari uraian mengenai teori kepastian hukum di atas maka dapat dikatakan bahwa kepastian hukum dalam pendaftaran tanah pada hakikatnya adalah jaminan perlindungan yang diberikan kepada pemegang hak atas tanah namun demikian dalam kerangka penyelenggaraan negara Indonesia sebagai negara hukum yang memberikan jaminan hak kepada seluruh masyarakat Indonesia maka dalam penyelenggaraan pendaftaran tanah, upaya perlindungan hukum kepada pihak yang mengajukan keberatan atas sebidang tanah yang telah terdaftar diberikan pula perlindungan hukum yang pada dasarnya berpijak pada upaya mencegah timbulnya permasalahan yang lebih rumit dan merugikan banyak pihak apabila pemblokiran tersebut tidak dilaksanakan.

\section{Landasan Sosiologis}

Landasan sosiologis berkaitan kemanfaatan bagi masyarakat sehingga dalam hal ini dibahas mengenai keterkaitan pemblokiran buku tanah dengan kemanfaatan bagi pihak-pihak yang berkaitan. Landasan sosiologi harus mencerminkan kenyataan hidup dalam masyarakat sehingga dapat diterima masyarakat dan mempunyai daya laku efektif dan tidak banyak memerlukan pengarahan institusi/ penegak hukum dalam melaksanakannya. ${ }^{14}$ Tatanan konsep hak atas tanah dalam hukum nasional Indonesia, ada beberapa hal yang tergolong bersifat pribadi. Sifat pribadi hak-hak individual menunjuk kepada kewenangan pemegang hak untuk menggunakan tanah yang bersangkutan bagi kepentingan dan dalam memenuhi kebutuhan pribadi dan keluarganya. Hal ini ditegaskan dalam Pasal 9 ayat 2 UUPA, yang menyatakan, bahwa: Tiap-tiap warganegara Indonesia baik laki-laki maupun wanita mempunyai kesempatan yang sama untuk memperoleh sesuatu hak atas tanah serta untuk mendapat manfaat dan hasilnya, baik bagi diri sendiri maupun keluarganya. Kata-kata untuk

\footnotetext{
${ }^{13}$ Christine Kansil, dkk. 2009. Kamus Istilah Hukum: Jakarta. (385).

${ }^{14}$ Diyan Ricky Warisle dan Agus Sekarmadji. Kepastian Hukum Sertipikat Hak Milik Masyarakat Hukum Adat Tengger.Jurnal Jurist-Diction, Vol. 2 Nomor 6 November 2019. (2063)
}

mendapat manfaat dan hasilnya, baik bagi diri sendiri maupun keluarganya menunjukkan sifat pribadi dari hak-hak atas tanah dalam konsepsi Hukum Tanah Nasional. ${ }^{15}$

Pengajuan pemblokiran oleh satu pihak adalah merupakan ruang baginya untuk memperoleh hak atas sebidang tanah yang dapat memberikan manfaat untuknya dan keluarganya sehingga hal ini menjadi salah satu landasan untuk melakukan pemblokiran atas sebidang tanah. Namun, demikian pelaksanaan pemblokiran haruslah diatur sedemikian rupa sehingga tidak menimbulkan kesewenangwenangan kepada pemegang hak atas tanah olehnya itu dibuatlah pengaturan mengenai pemblokiran yang memberikan batasan dan rambu-rambu sehingga pemblokiran menempatkan kepentingan semua pihak dalam kesempatan yang sama dalam mempertahankan hak yang diklaimnya. ${ }^{16}$ Manfaat pemblokiran tidak hanya untuk para pihak tetapi juga untuk lembaga pertanahan karena dengan adanya pemblokiran maka lembaga pertanahan dapat melakukan antisipasi atau pencegahan secara dini terhadap perbuatan hukum atas sebidang tanah yang sedang dalam perkara ataupun sita sehingga tidak akan menimbulkan kerumitan di kemudian hari dalam menindaklanjuti penyelesaian atas masalah yang ada. ${ }^{17}$ Beberapa substansi hukum yang mengatur pemblokiran atas buku tanah adalah Peraturan Pemerintah No. 24 tahun 1997 tentang Pendaftaran Tanah, Keputusan Kepala Badan Pertanahan Nasional No. 3 Tahun 1997 tentang Peraturan Pelaksanan Peraturan Pemerintah No. 24 Tahun 1997 tentang Pendaftaran Tanah, Peraturan Menteri Agraria /Kepala Badan Pertanahan Nasional No. 13 tahun 2017 tentang Tata Cara Blokir dan Sita.

\footnotetext{
${ }^{15}$ Kadek Julia Mahadewi. Tinjauan Yuridis Karakteristik Penggunaan Hak Pakai dalam Kepemilikan Apartemen oleh Warga Negara Asing di Indonesia. Jurnal Gema Keadilan, Volume 6, Edisi II, Agustus 2019. (184)

${ }^{16}$ Kurnia Martini Dwi Putri A.T. Status Hukum Peralihan Hak Atas Tanah Yang Diperoleh Dari Lelang Berdasarkan Hak Mendahulu Negara. Fiat Justisia Journal Volume 10 Issue 3, July-September 2016. (503)

${ }^{17}$ Tri Hayati. Hak Penguasaan Negara Terhadap Sumber Daya Alam Dan Implikasinya Terhadap Bentuk Pengusahaan Pertambangan. Jurnal Hukum dan Pembangunan 49 No. 3 (2019): 768
} 
Peraturan perundang-undangan yang disebutkan di atas masih mengandung kelemahan antara lain beberapa aturan tidak sistematis dan tidak terklarifikasi sehingga tidak ada perbedaan antara pemblokiran karena sita dan pemblokiran karena perkara serta pengaturan jangka waktu pemblokiran tidak sesuai dengan aturan mengenai jangka waktu maksimal pemerikasaan oleh pengadilan .

Dari seluruh uraian di atas maka dapat dikatakan bahwa pengaturan pemblokiran buku tanah pendaftaran hak atas tanah belum dapat memenuhi tujuan filosofis, yuridis dan sosiologis karena masih mengandung substansi hukum yang tidak jelas, multi tafsir dan saling bertentangan sehingga tidak sepenuhnya memberikan perlindungan hukum, kepastian hukum dan kemanfaatan bagi pemegang hak atas tanah.

\section{B. Mekanisme Pembokiran Pada Buku Tanah dalam Rangka Mewujudkan Kepastian Hukum Pemegang Hak atas Tanah}

Pendaftaran hak atas tanah di indonesia sebagaimana diatur dalam UUPA dan PP No. 24 Tahun 1997 adalah untuk menjamin kepastian hukum hak atas tanah. Namun demikian, sistem pendaftaran tanah di Indonesia belum menerapkan sistem positif sehingga dalam hal terdapat pihak lain yang dapat membuktikan sebaliknya maka hak atas tanah yang dimiliki seseorang dapat menjadi gugur. Hal yang menyebabkan timbulnya kondisi ini adalah terjadinya sengketa atas bidang tanah. ${ }^{18}$ Dalam pelaksanaan pemblokiran buku tanah pada terdapat beberapa alasan yang diajukan oleh pihak pemohon yaitu alasan sengketa atau konflik, alasan perkara, sita, jaminan utang piutang dan sertifikat hilang.

Permohonan pemblokiran melalui surat biasa ditujukan kepada Kepala Kantor Pertanahan dan untuk jenis permohonan seperti ini pada umumnya didisposisikan ke seksi Penanganan Masalah dan Pengendalian Pertanahan untuk ditindaklanjuti penanganannya sesuai ketentuan Peraturan Menteri Agraria No. 11 Tahun 2016. Sedangkan untuk permohonan pemblokiran melalui loket

18 J. Ronald Mawuntu. Konsep Penguasaan Negara Berdasarkan Pasal 33 UUD NRI dan Putusan Mahmakah Konstitusi. Jurnal Hukum Vol. XX.No. 3 April - Juni Tahun 2012 pendaftaran hak dilakukan dengan mendaftarkan melalui KKP Kantor Pertanahan dengan membayar Penerimaan Negara Bukan Pajak ke negara sebesar Rp. 50.000. Untuk jenis permohonan ini, akan diteruskan ke seksi hubungan hukum pertanahan. Untuk permohonan pemblokiran melalui surat resmi, dalam hal tidak terdapat dokumen pendukung yang cukup, akan disampaikan secara tertulis kepada yang bersangkutan untuk melengkapinya sedangkan untuk pendaftaran melalui loket, penginputan dalam KKP Kantor Pertanahan baru dilaksanakan apabila semua dokumen yang diperlukan sudah dilengkapi oleh yang bersangkutan. Dokumen pendukung yang dimaksud adalah fotocopi Kartu tanda Penduduk yang dilegalisir, fotocopi Kartu Keluarga yang dilegalisir, fotocopy dasar pemblokiran baik berupa akta maupun suratsurat lain yang berkaitan dengan alasan pemblokiran.

Dalam pelaksanaan pemblokiran yang disampaikan melalui surat tertulis, langkah yang ditempuh setelah semua dokumen lengkap adalah mengundang pihak yang mengajukan pemblokiran untuk meminta keterangan terkait pemblokiran yang diajukan dan mmepertanyakan langkah yang diinginkan oleh pihak yang bermohon tersebut. Pada umumnya, mereka meminta dipertemukan dengan pemegang hak atas tanah untuk dimediasi. Pada saat pelaksanaan mediasi dan tidak ditemukan solusi damai maka kepada pihak yang mengajukan pemblokiran disampaikan surat yang pada pokoknya memberikan tenggang waktu 30 (tiga puluh) hari untuk mengajukan upaya hukum sejak diterimanya surat tersebut dan apabila setelah 30 (tiga puluh) hari tidak dilakukan upaya hukum maka pemblokiran tersebut hapus dengan sendirinya.

Untuk pelaksanaan pemblokiran melalui KKP kantor pertanahan, setelah Kepala Seksi Hubungan Hukum menerima permohona tersebut, ia membuat Nota Dinas ke seksi Penanganan Masalah dan Pengendalian Pertanahan untuk dilakukan pengkajian dan analisis mengenai tindak lanjut atas permohonan tersebut. Pada umumnya bahkan hampir seluruh permohonan pemblokiran ternyata diterima dengan syarat menunggu 30 (tiga puluh) hari untuk pengajuan gugatan dan 
apabila gugatan tidak diajukan maka pemblokiran dalam sertipikat hak atas tanah akan hapus secara otomatis.

Mencermati kedua cara pengajuan permohonan pemblokiran tersebut, dapat dikatakan bahwa baik cara pertama maupun cara kedua pada akhirnya melakukan upaya yang sama yaitu memberikan waktu 30 (tiga puluh) hari untuk pengajuan gugatan ke pengadilan dan hanya sebagian dari permohonan pemblokiran yang benar-benar mengajukan gugatan namun dalam wawancara tersebut disebutkan bahwa meskipun telah terlampaui waktu 30 hari tersebut namun jika tidak ada suatu layanan yang diminta oleh pemegang hak atas tanah, catatan blokir tersebut tetap tertulis pada buku tanah. Jika suatu hari kelak, pemegang hak melakukan kegiatan pendaftaran peralihan atau pemelihataan data apapun, barulah seksi hubungan hukum pertanahan meminta kepada seksi Penanganan Masalah dan Pengendalian Pertanahan untuk membuat analisis dapat tidaknya catatan pemblokiran di hapuskan. Permasalahan menjadi rumit apabila tidak ada proses pendaftaran peralihan atau peralihan data yang diajukan pemegang hak maka selamanya catatan blokir tersebut akan tercatat dalam buku tanah. Hal ini merupakan salah satu bentuk tidak terlindungi pemegang hak atas tanah dari pemblokiran yang tidak disertai alasan dan dasar yang jelas. Pengajuan pencatatan ataupun pemblokiran sebagaimana diatur dalam Peraturan Menteri Agraria/kepala Badan Pertanahan Nasional No. 13 Tahun 2017 hanya dapat diajukan satu kali sehingga apabila telah habis jangka waktu 30 hari sejak pencatatan atau pemblokiran dilakukan maka pihak yang mengajukan keberatan tidak dapat mengajukan lagi permohonan yang sama. Pihak yang dapat mengajukan pemblokiran bukan hanya pihak yang keberatan tetapi dapat pula diajukan oleh pihak perbankan, pihak aparat penegak hukum atau pihak lain yang memiliki hubungan hukum yang layak dipercaya berdasarkan dokumen yang diajukan. ${ }^{19}$

Dari uraian di atas dapat dilihat bahwa pihak yang mengajukan pemblokiran dalam Peraturan Menteri Agraria/kepala Badan

\footnotetext{
19 Hasil wawancara dengan Kepala Seksi Penangana Masalah dan Pengendalian Pertanahan Kantor Pertanahan Kota Manado tanggal 17 Maret 2020.
}

Pertanahan Nasional No. 13 Tahun 2017 adalah pihak yang bersengketa, aparat penegak hukum dan pihak perbankan. Namun demikian, terdapat pula pengajuan pemblokiran oleh calon pembeli yaitu pihak yang telah membuat akta pengikatan jual beli atas tanah. Pihak calon pembeli mengajukan pemblokiran dengan alasan mencegah timbulnya perbuatan dari pihak penjual yakni menjual tanahnya yang sedang dalam masa penyelesaian pembayaran oleh pembeli, kepada pihak lain. Hal ini menurut narasumber tidak diatur dalam aturan pendaftaran hak ataupun aturan tentang pemblokiran sehingga tidak dapat ditindaklanjuti karena tidak dapat diakomodir oleh sistem aplikasi KKP Kantor Pertanahan. Menanggapi kondisi di atas terkait dengan tidak dilaksanakannya pemblokiran karena tidak diakomodir oleh aplikasi KKP Kantor Pertanahan, peneliti berpandangan bahwa sebuah aplikasi seharusnya dirancang dan dibangun berdasarkan peraturan perundangundangan yang berlaku atas sistem yang dirancang pada aplikasi. Jika terdapat satu kegiatan yang tidak dapat didaftarkan dalam aplikasi sementara peraturan perundangundangan telah mengaturnya, seharusnya dterdapat upaya dari Badan Pertanahan Nasional untuk melakukan pembaharuan terhadap aplikasi yang digunakan agar sejalan dengan peraturan perundang-undangan.

Pihak yang dapat mengajukan permohonan pencatatan blokir sertipikat hak atas tanah adalah pemohon yang mempunyai hubungan/ kepentingan hukum terhadap tanah yang sedang dalam sengketa maupun menjadi objek perkara di pengadilan. Pemohon yang mengajukan permohonan diantaranya adalah: pemegang hak atas tanah, pihak pembeli, ahli waris, pengadilan negeri, kepolisian, advokad (kuasa hukum), bank, dan KPK.

Dalam pelaksanaan pemblokiran buku tanah di Kantor Prtanahan Kota Manado terdapat beberapa hal yang sangat rentan dengan ketidakpastian hukum bagi pemegang hak atas tanah yaitu :

a) Peraturan Menteri Kepala BPN Nomor 3 Tahun 1997 dan Peraturan Menteri Agraria No. 13 Tahun 2017 telah mengatur tentang jangka waktu pemblokiran di kantor pertanahan yaitu 30 (tiga puluh) hari terhitung sejak 
tanggal pencatatan blokir. Kenyataannya jangka waktu pemblokiran di Kantor Pertanahan kota Manado tetap berlangsung selama pihak pemblokir belum mencabut permohonan blokirnya karena berkas permohonan blokir yang sudah didaftarkan di KKPweb belum dapat mengakomodir akan hapus dengan sendirinya setelah lewat 30 hari kecuali ada permohonan pencabutan blokir yang diajukan oleh pemohon dan merupakan prinsip kehati-hatian kantor pertanahan untuk tetap mencatat blokir sampai dengan adanya pencabutan blokir karena adanya blokir adalah suatu indikasi akan adanya sengketa pertanahan. Jika mengacu pada aturan maka blokir hanya berlaku 30 hari dan akan hapus dengan sendirinya kecuali dapat diperpanjang dengan adanya perintah berupa penetapan atau putusan (Pasal 13 Peraturan Menteri ATR/ Kepala BPN Nomor 13 Tahun 2017). Hal tersebut merugikan pihak pemilik sertipikat atau pihak terblokir karena tidak bisa melakukan perbuatan hukum sebelum blokir dicabut

b) Pihak Kantor Pertanahan Kota Manado melakukan pemblokiran terhadap bidang tanah yang sedang menjadi objek hak tanggungan yang dicatatkan pemblokiran meskipun mekanisme yang digunakan untuk memblokir bukan melalui pendaftaran di loket tetapi melalui mekanisme persuratan biasa. Diterimanya pemblokiran atas buku tanah hak atas tanah yang sedang menjadi hak tanggungan didasari oleh pandangan bahwa dalam Peraturan Menteri Agraria/Kepala Badan Pertanahan Nasional No. 13 Tahun 2017 tidak ada satupun ketentuan yang melarang pencatatan blokir atas sertipikat yang menjadi objek hak tanggungan. Aturan ini hanya melarang penblokira atas asset negara/daerah/BUMN/BUMD.Hal ini jelas perlu dicermati lagi karena hak tanggungan diatur dalam Undangundang No. 4 Tahun 1996 telah secara tegas mengatur adanya kekuatan eksekutorial pada sertipikat hak tanggungan dengan dicantumkannya irah-irah "demi keadilan berdasarkan Ketuhanan yang Maha Esa." Hal ini menyebabkan pemblokiran terhadap sertipikat hak tanggungan harus ditinjau kembali karena sertipikat hak tanggungan mempunyai kekuatan eksekutorial yang sama dengan putusan pengadilan yang telah memperoleh kekuatan hukum tetap, dengan diterimanya permohonan pencatatan blokir di Kantor Pertanahan Kota Manado maka dapat dikatakan titel eksekutorial tidak terlaksana secara yuridis hak atas tanah yang dibebani hak tanggungan telah dilindungi oleh undang-undang hak tanggungan dan mempunyai kekuatan hukum tetap secara hierarki dalam pencatatan blokir oleh kantor pertanahan dengan dasar peraturan lain yang tingkatannya dibawah undangundang seharusnya tidak dapat dilaksanakan. Pemblokiran atas hak atas tanah yang telah dibebani dengan hak tanggungan yang dijadikan jaminan kredit di dalam dunia busines sangat mengganggu didalam cash flow usaha debitor dan secara materiil sangat merugikan karena APHT tersebut tidak bisa dilakukan untuk perpanjangan, penambahan, perubahan dan pembaharuan utang dan tidak bisa melakukan lelang sehingga selama waktu 30 hari tidak bisa untuk melakukan perbuatan hukum. Padahal sertipikat Hak atas Tanah yang dibebani dengan hak tanggungan yang mana tata cara dan lahirnya akta pemberian hak tanggungan dari mulai melakukan cek sertipikat, mendaftarkan hak tanggungan sampai dengan penerbitan sertipikat hak tanggungan dibuat oleh kantor pertanahan.

c) Permohonan pendaftaran hak atas tanah dan pemeliharaan data pendaftaran hak atas tanah saat ini dilaksanakan melalui aplikasi web yang disebut KKP kantor Pertanahan. Keberadaan KKP ini untuk memudahkan pengawasan dan pengendalian terhadap alur berkas sehingga pelayanan menjadi cepat. Namun demikian, keberadaan KKP ini 
ternyata tidak secara penuh mengakomodir hal-hal yang sifatnya yuridis sehingga dapat menimbulkan masalah bagi pemegang hak. Dalam hal dilakukan pemblokiran melalui aplikasi KKP, ternyata untuk dapat mencabut blokir tersebut, haruslah pihak yang mengajukan pemblokiran padahal dalam aspek yuridisnya, pihak yang dapat mencabut pemblokiran tersebut adalah pihak yang memilihi hak atas bidang tanah itu. Jadi, meskipun pihak lain yang mengajukan blokir jika kemudian terdapat putusan yang memenangkan pemegang hak maka berdasarkan putusan tersebut, pemegang hak atas tanah dapat mengajukan permohonan pencabutan blokir.

d) Penerapan aplikasi KKP kantor pertanahan yang tidak mengakomodir secara keseluruhan aturan-aturan di bidang pertanahan dan tidak dilakukan pembaharuan aplikasi berdasarkan pembaharuan peratura perundangundangan menimbulkan permasaalahan terkait dengan pemblokiran karena aplikasi ini belum melakukan penghapusan secara mutatis mutandis apabila jangka waktu 30 hari terlewati.

e) Timbulnya ketakutan dalam melaksanakan kewenangan dalam penolakan permohonan pemblokiran karena aparat penegak hukum dalam realitasnya banyak melakukan peemriksaan terhadap para pelaksana apabila terdapat keberatan dan permohonan hak tetap dilanjutkan sehingga seluruh permohonan blokir ditindaklanjuti meskipun tidak memiliki dasar yang jelas. Hal ini menyebabkan kerumitan bagi pemegang hak atas tanah karena hak mereka terhalangi oleh keberatan yang tidak beralasan sama sekali. Seharunya Kantor pertanahan tidak serta merta menerima permohonan blokir yang masuk namun harus memastikan bahwa pemohon pencatatan blokir benar-benar mempunyai hubungan hukum terhadap tanah yang akan diblokir.

f) Penggunaan aplikasi sistem informs penanganan masalah pertanahan di mana setiap permasalahan harus diinput menyebabkan tidak ada filter terhadap keberatan yang beralasan dan tidak beralasan. Sistem informasi penanganan permasalahan melakukan pemblokiran secara otomatis apabila sebidang tanah bersertipikat diinput sebagai objek sengketa. Hal ini seharusnya perlu ditinjau ulang misalnya dengan melakukan pengaturan penginputan masalah pertanahan baru dilakukan ketika masalah tersebut sudah dilakukan analisis dan dapat dipertimbangkan untuk ditindaklanjuti.

g) Pemblokiran dilakukan terhadap bidang tanah yang telah beralih kepada pihak lain sehingga perlindungan hukum pembeli beriktikad baik menjadi terganggu.

h) Dalam pelaksanaan pemblokiran buku tanah, realitasnya adalah tidak melakukan pembedaan antara pemblokiran dengan pencatatan pada hal keduanya memiliki sebab dan dampak yang berbeda. Pencatatan dalam buku tanah dilakukan apabila catatan adanya sengketa,konflik dan perkara pertananan tidak dilakukan melalui loket pendaftaran hak tetapi hak melalui persuaratan biasa sedangkan peemblokiran dilakukan melalui pendaftaran pada loket sehingga kepada pemohon dibebankan kewajiban untuk melakukan pembayaran PNBP ke negara.

Pemblokiran yang tidak sesuai dengan Permen ATR/Ka.BPN 13 Tahun 2017 tidak hanya mengakibatkan kepastian hukum tidak terwujud, melainkan juga menimbulkan kerugian bagi pemilik sertipikat terblokir, baik kerugian materiil maupun idiil. Kerugian materiil meliputi kerugian yang nyata diderita dan tidak diperolehnya keuntungan, sedangkan kerugian immateriil misalnya ketakutan, sakit, kehilangan kesenangan hidup. Blokir perkara dalam contoh kasus sub-bab di atas, berpotensi menimbulkan kerugian finansial terhadap pemilik sertipikat terblokir.

Pasal 1365 KUHPerdata tentang Perbuatan Melawan Hukum (PMH) diatur bahwa tiap perbuatan melanggar hukum, yang membawa kerugian kepada orang lain, mewajibkan orang yang karena salahnya menerbitkan kerugian itu, 
menggantikan kerugian tersebut. Sesuai Pasal 1365, perbuatan melawan hukum atau "onrechtmatige daad" diartikan secara sempit, hanya mengenai perbuatan yang langsung melanggar suatu peraturan hukum. Perbuatan Melawan Hukum dalam arti luas sebagai berbuat tidak berbuat yang bertentangan dengan kewajiban hukum si pembuat, atau yang bertentangan dengan kesusilaan atau dengan kepatutan dalam masyarakat terhadap diri atau benda orang lain.

Kepastian Hukum Sertipikat Hak Atas Tanah, meliputi: Kepastian hukum status hak atas tanah yang didaftar, Kepastian hukum subyek hak atas tanah, Kepastian hukum obyek hak atas tanah. Kepastian Hukum Sertipikat Hak Atas Tanah yang diterbitkan PP No. 24 Tahun 1997 yang menganut sistem publikasi negatif bertendensi positif: Sertipikat hak atas tanah merupakan surat tanda bukti hak yang kuat tetapi tidak mutlak. Hal tersebut dapat dilihat dalam penjabaran ketentuan Pasal 19 Ayat (2) huruf c, Pasal 23 Ayat (2), Pasal 32 Ayat (2), dan Pasal 38 Ayat (2) UUPA, bahwa "sistem publikasi pendaftaran tanah yang dianut adalah sitem publikasi negatif, yaitu sertipikat hanya merupakan surat tanda bukti hak yang bersifat kuat dan bukan merupakan surat tanda bukti hak yang bersifat mutlak".14 Walaupun ketentuan Pasal 32 Ayat (1) PP No. 24 Tahun 1997 menyebutkan: "Sertipikat merupakan surat tanda bukti hak yang berlaku sebagai alat pembuktian yang kuat mengenai data fisik dan data yuridis yang termuat di dalamnya, sepanjang data fisik dan data yuridis tersebut sesuai dengan data yang ada dalam surat ukur dan buku tanah hak yang bersangkutan.

Tujuan hukum adalah mewujudkan kepastian hukum sekaligus keadilan bagi masyarakat sebagaimana menurut Aristoteles dan Aguinas Grotius yang mengajarkan bahwa kepastian hukum dan keadilan adalah tujuan dari sistem hukum. Demikian juga ketentuna pasal 19 Ayat (2) UUPA menegaskan bahwa pemberian surat tanda bukti hak (sertifikat) yang berlaku sebagai alat pembuktian yang kuat, ini sesuai pula dengan penjelasan atas UUPA Bab IV alinea 2 yang menyebutkan pendaftaran tanah yang bersifat rechtkadaster yang artinya bertujuan menjamin kepastian hukum. $^{20}$ Kepastian hukum sertifikat seharusnya dapat dipahami sebagai sertifikat yang merupakan produk dari lembaga pemerintah adalah sesuatu sebagai alat bukti kepemilikan hak atas tanah yang tidak dapat di gangu gugat lagi. Akan tetapi sebagaimana penjelasan pasal 32 Ayat (1) PP No. 24 Tahun 1997 sertifikat merupakan tanda bukti yang kuat selama tidak dapat dibuktikan sebaliknya data fisik dan data yuridis yang tercantum didalamnya diterima sebagai data yang benar. Ini dapat disimpulkan bahwa sertifikat sebagai produk lembaga pemerintah ada kemungkinan tidak benar (terlepas dari sebab-sebabnya), dengan demikian dapat mengurangi arti kepastian hukum sertifikat itu sendiri.

Kepastian hukum menurut pendapat Jan Michiel Otto dalam bukunya Adrian Sutendi, bahwa untuk menciptakan kepastian hukum harus memenuhi syarat-syarat sebagai berikut: (1) Ada aturan hukum yang jelas dan konsisten; (2) Instansi pemerintah menerapkan aturan hukum secara konsisten, tunduk dan taat terhadapnya; (3) Masyarakat menyesuaikan perilaku mereka terhadap aturan hukum tersebut; (4) Hakim-hakim yang mandiri, tidak berpihak dan harus menerapkan aturan hukum secara konsisten serta jeli sewaktu menyelesaikan sengketa hukum; (5) Putusan pengadilan secara konkrit dilaksanakan. ${ }^{21}$

Pemblokiran buku tanah karena adanya sengketa, perkara, sita merupakan wadah yang disiapkan oleh negara bagi mereka yang merasa haknya terlanggar karena adanya penerbitan sertipikat atau merasa haknya dapat terlanggar apabila dilakukan perbuatan hukum atas tanah tersebut namun demikian perlindungan hukum terhada mereka tidaklah berarti bahwa keberadaan sertipikat hak atas tanah sebagai jaminan kepastian hukum direduksi oleh pelaksanaan pemblokiran yang tidak didasarkan pada peraturan perundangundangan.

Mekanisme pemblokiran pada buku tanah dalam pendaftaran tanah belum dapat menjamin kepastian hukum bagi pihak

\footnotetext{
20 Athari Farhani dan Ibnu Sina Chandranegara. Penguasaan Negara terhadap Pemanfaatan Sumber Daya Alam Ruang Angkasa Menurut Undang-Undang Dasar Negara Republik Indonesia Tahun 1945. Jurnal Konstitusi Volume 16 Nomor 2 Juni 2019

${ }^{21}$ Adrian Sutedi, 2011, Sertifikat Hak Atas Tanah, Sinar
} Grafika, Jakarta, hlm. 27. (187 halaman). 
pemegang hak atas tanah di Kota Manado karena belum dilaksanakan berdasarkan peraturan perundang-undangan bidang pertanahan yang mengatur tentang pemblokiran serta terdapat hambatan yang menyebabkan kepastian hukum belum dapat tercapai antara lain penggunaan teknologi yang belum diselaraskan dengan peraturan perundang-undangan serta ketakutan aparat BPN untuk konsisten dalam melakukan penghapusan setelah jangka waktu 30 hari akibat pemahaman aparat penegak hukum yang belum sepenuhnya mengetahui mekanisme pemblokiran.

\section{PENUTUP}

\section{A. Kesimpulan}

1. Pengaturan Pemblokiran Pada Buku Tanah Dalam Sistem Pendaftaran Tanah dapat dilihat dari 3 (tiga) aspek yaitu pertama aspek filosofis yakni bentuk perlindungan hukum preventif atas kemungkinan timbulnya kerugian beberapa pihak dalam hal terjadinya sengketa, konflik atau perkara atas sebidang tanah yang telah terdaftar haknya. Kedua, aspek yuridis, pengaturan pemblokiran buku tanah merupaka upaya untuk mewujudkan kepastian hukum dalam pelaksanaan pemblokiran agar tidak menimbulkan ketidakteraturan dan kewenang wenangan bagi pihak pemegang hak atas tanah. Ketiga, pengaturan pemblokiran antisipasi atau pencegahan secara dini terhadap perbuatan hukum atas sebidang tanah yang sedang dalam perkara ataupun sita sehingga tidak akan menimbulkan kerumitan di kemudian hari dalam menindaklanjuti penyelesaian atas masalah yang ada.

2. Mekanisme pemblokiran pada buku tanah dalam pendaftaran tanah belum dapat menjamin kepastian hukum bagi pihak pemegang hak atas tanah di karena belum dilaksanakan berdasarkan peraturan perundang-undangan bidang pertanahan yang mengatur tentang pemblokiran serta terdapat hambatan yang menyebabkan kepastian hukum belum dapat tercapai antara lain penggunaan teknologi yang belum diselaraskan dengan peraturan perundang-undangan serta ketakutan aparat BPN untuk konsisten dalam melakukan penghapusan setelah jangka waktu 30 hari akibat pemahaman aparat penegak hukum yang belum sepenuhnya mengetahui mekanisme pemblokiran.

\section{B. Saran}

1. Perlu dilakukan perbaikan terhadap beberapa substansi hukum dalam Peraturan Menteri Agraria/Kepala BPN NO. 13 Tahun 2017 karena menimbulkan ketidakjelasan dalam penerapannya.

2. penggunaan teknologi KKP kantor pertanahan seharusnya sejalan dengan peraturan perundang-undangan bidang pertanahan terkait dengan pemblokiran.

\section{DAFTAR BACAAN}

Adrian Sutedi, 2011, Sertifikat Hak Atas Tanah, Sinar Grafika, Jakarta

Athari Farhani dan Ibnu Sina Chandranegara. Penguasaan Negara terhadap Pemanfaatan Sumber Daya Alam Ruang Angkasa Menurut Undang-Undang Dasar Negara Republik Indonesia Tahun 1945. Jurnal Konstitusi Volume 16 Nomor 2 Juni 2019

Christine Kansil, dkk. 2009. Kamus Istilah Hukum : Jakarta.

Diyan Ricky Warisle dan Agus Sekarmadji. Kepastian Hukum Sertipikat Hak Milik Masyarakat Hukum Adat Tengger.Jurnal Jurist-Diction, Vol. 2 Nomor 6 November 2019.

Fadli Zon, Muhammad Iskandar dan Susanto Zuhdi. Tinjauan Sejarah Hukum Pasal 33 Uud 1945 Sebagai Ideologi Ekonomi. Jurnal Negara Hukum, Volume 7 No. 1 Tahun 2016.

Isdiyana Kusuma Ayu. Kepastian Hukum Penguasaan Tanah Melalui Pendaftaran Tanah Sistematis Lengkap Di Kota Batu. Jurnal Mimbar Hukum Volume 31, Nomor 3, Oktober 2019.

Iwan Permadi. Perlindungan Hukum Terhadap Pembeli Tanah Bersertifikat Ganda Dengan Cara Itikad Baik Demi Kepastian Hukum, Jurnal Yustisia, Volume 5 No. 2 Mei-Agustus 2016. 
Kadek Julia Mahadewi. Tinjauan Yuridis Karakteristik Penggunaan Hak Pakai dalam Kepemilikan Apartemen oleh Warga Negara Asing di Indonesia. Jurnal Gema Keadilan, Volume 6, Edisi II, Agustus 2019.

Kurnia Martini Dwi Putri A.T. Status Hukum Peralihan Hak Atas Tanah Yang Diperoleh Dari Lelang Berdasarkan Hak Mendahulu Negara. Fiat Justisia Journal Volume 10 Issue 3, July-September 2016.

J. Ronald Mawuntu. Konsep Penguasaan Negara Berdasarkan Pasal 33 UUD NRI dan Putusan Mahmakah Konstitusi. Jurnal Hukum Vol. XX.No. 3 April - Juni Tahun 2012

Peter Mahmud Marzuki. 2002. Penelitian Hukum, Yuridika (Jurnal Ilmu Hukum Fakultas Hukum Universitas Airlangga Surabaya Vol. 16 No. 2.

Sri Wijayanti. 2010. Kepastian Hukum Sertipikat Hak Atas Tanah Sebagai Bukti Hak Kepemilikan Tanah (Studi Kasus Putusan MA Tentang Sengketa Tanah Meruya Selatan), Tesis, Universitas Diponegoro: Semarang.

Terry Hutchinson. 2002. Researching and Writing In Law. Law Book CO Pyrmon : NSW

Tri Hayati. Hak Penguasaan Negara Terhadap Sumber Daya Alam Dan Implikasinya Terhadap Bentuk Pengusahaan Pertambangan. Jurnal Hukum dan Pembangunan 49 No. 3 (2019):

Urip Santoso. 2010. Hukum Agraria, Kajian Komprehensif. Kencana : Jakarta. 